Article

\title{
Creating a Lowland and Peatland Landscape Digital Terrain Model (DTM) from Interpolated Partial Coverage LiDAR Data for Central Kalimantan and East Sumatra, Indonesia
}

\author{
Ronald Vernimmen ${ }^{1, *(1)}$, Aljosja Hooijer ${ }^{1}$, Angga T. Yuherdha ${ }^{1}\left(\mathbb{C}\right.$, Martijn Visser ${ }^{1}{ }^{(0)}$, \\ Maarten Pronk ${ }^{1}{ }^{\circledR}$, Dirk Eilander ${ }^{1}{ }^{\circledR}$, Rizka Akmalia ${ }^{1}$, Natan Fitranatanegara ${ }^{1}$, Dedi Mulyadi ${ }^{1}$, \\ Heri Andreas ${ }^{2}$, James Ouellette ${ }^{3}$ and Warwick Hadley ${ }^{3}$ \\ 1 Deltares, Inland Water Systems Unit, P.O. Box 177, Delft 2600 MH, The Netherlands; \\ aljosja.hooijer@deltares.nl (A.H.); angga.yuherdha@deltares.nl (A.Y.T.); martijn.visser@deltares.nl (M.V.); \\ maarten.pronk@deltares.nl (M.P.); dirk.eilander@deltares.nl (D.E.); rizka.akmalia@deltares.nl (R.A.); \\ natannegara@gmail.com (N.F.); dedi_mulyadi_wm@yahoo.com (D.M.) \\ 2 Geodesy Research Group, Institute of Technology Bandung (ITB), Jl. Ganesha 10, Bandung 40132, Indonesia; \\ heri@gd.itb.ac.id \\ 3 PT Surtech Prima, Jl. Ampera Raya No 5, Jakarta 12560, Indonesia; james.ouellette@surtech-group.com (J.O.); \\ warwick.hadley@surtech-group.com (W.H.) \\ * Correspondence: ronald.vernimmen@deltares.nl
}

Received: 9 April 2019; Accepted: 13 May 2019; Published: 14 May 2019

\begin{abstract}
Coastal lowland areas support much of the world population on only a small part of its terrestrial surface. Yet these areas face rapidly increasing land surface subsidence and flooding, and are most vulnerable to future sea level rise. The accurate and up to date digital terrain models (DTMs) that are required to predict and manage such risks are absent in many of the areas affected, especially in regions where populations are least developed economically and may be least resilient to such changes. Airborne LiDAR is widely seen as the most accurate data type for elevation mapping but can be prohibitively expensive, as are detailed field surveys across a broad geographic scale. We present an economical method that utilizes airborne LiDAR data along parallel flight lines ('strips') covering between $10 \%$ and $35 \%$ of the land depending on terrain characteristics, and manual interpolation. We present results for lowland areas in Central Kalimantan and East Sumatra (Indonesia), for which no accurate DTM currently exists. The study areas are covered with forest, plantations and agricultural land, on mineral soils and peatlands. The method is shown to yield DTM differences within $0.5 \mathrm{~m}$, relative to full coverage LiDAR data, for $87.7-96.4 \%$ of the land surface in a range of conditions in 15 validation areas, and within $1.0 \mathrm{~m}$ for $99.3 \%$ of the area overall. After testing, the method was then applied to the entire eastern coastal zone of Sumatra, yielding a DTM at $100 \mathrm{~m}$ spatial resolution covering 7.1 Mha of lowland area from 1.45 Mha of effective LiDAR coverage. The DTM shows that $36.3 \%$, or $2.6 \mathrm{Mha}$, of this area is below $2 \mathrm{~m}+\mathrm{MSL}$ and, therefore, at risk of flooding in the near future as sea level rise continues. This DTM product is available for use in flood risk mapping, peatland mapping and other applications.
\end{abstract}

Keywords: LiDAR; DTM; lowland; peatland; Central Kalimantan; East Sumatra; Indonesia

\section{Introduction}

Coastal lowland areas including river deltas host much of the world's population and economic activity on only a small proportion of its terrestrial area [1]. Yet they face rapidly increasing risks of 
flooding, as well as crop failure due to high water levels and saltwater intrusion in the channels, made worse by land surface subsidence and sea level rise [2-6].

Accurate and up to date digital terrain models (DTMs) are required to predict and manage such water level-related risks, but are absent in most of the areas affected. Instead, elevation models derived from Shuttle Radar Topography Mission (SRTM) data are still often used [1,7-10], but these can have a vertical error of many meters, especially in vegetated areas. While the bias correction method applied by [11] on the SRTM data increased the fraction of land areas having a vertical accuracy with $\pm 2 \mathrm{~m}$ or better from $39-58 \%$ of the world, it remains unsuitable for most applications in lowlands.

Airborne light detection and ranging (LiDAR) is a fast and accurate method for establishing land surface elevation models, especially in vegetated and built-up areas where other methods, such as satellite radar, are not suitable [11]. However, LiDAR is a costly technique, limiting its economical use to large landscapes, e.g., the hundreds of millions of hectares of lowland, globally, that urgently require such data for accurate modelling.

To overcome this financial obstacle and enable the coverage of large areas economically, we have developed an innovative approach that does not require 'full coverage' LiDAR data acquisition to generate a reliable DTM. Our approach is to cover approximately $10-35 \%$ of the area of interest, depending on scale, thus reducing the time for data acquisition and its cost by 3-10 times. Reducing the data acquisition time is beneficial for urgent applications or in regions where conditions suitable for airborne LiDAR data acquisition occur only during a limited period of the year.

The aim of this study is to test and validate the method in Indonesia, which has over 30 million hectares of coastal lowland [12] for which no accurate elevation models exist at present. Indonesian lowlands may be amongst the worst affected as sea level variability is higher than the global average [13], land surface subsidence is common in many rural $[5,14]$ and urban [15-17] areas and more than $60 \%$ of the Indonesian population lives in coastal zones [18].

\section{Materials and Methods}

\subsection{LiDAR Data Acquisition}

Discrete return small-footprint airborne LiDAR data was acquired in several lowland areas in Indonesia over the period 2011-2017 and was referenced to the national benchmarks installed by the Indonesian Geospatial Information Agency (BIG). In the Province of Central Kalimantan, full coverage data was acquired over 744,000 ha, some 75\% of the 'Ex-Mega Rice Project' lowland area (Figure 1), between 15 August and 15 October 2011. In Sumatra, LiDAR data and orthophotos were acquired in several different projects from 2014-2017 over the Provinces of Riau, Jambi and South Sumatra (Figure 1), yielding an effective LiDAR coverage area of 1.45 Mha. Flight lines were designed perpendicular to rivers and coastlines to maximize information content and facilitate interpolation. Data was acquired at four different coverage levels, with variable intervals between flight lines depending on land type and accuracy requirements. In tree plantations on peatland that require highly detailed DTMs (both in vertical accuracy as well as higher spatial resolution) for precise water management, flights were designed at $2.5 \mathrm{~km}$ intervals plus boundary canals. Over other peatlands LiDAR data were flown mostly at $5 \mathrm{~km}$ intervals which suffices for landscape scale DTMs that support land use zoning and general water management design. In mineral soil lowlands, which tend to be flatter than peatlands with less complex morphology, flight lines at 5-15 km intervals were applied with an average of around $10 \mathrm{~km}$. 

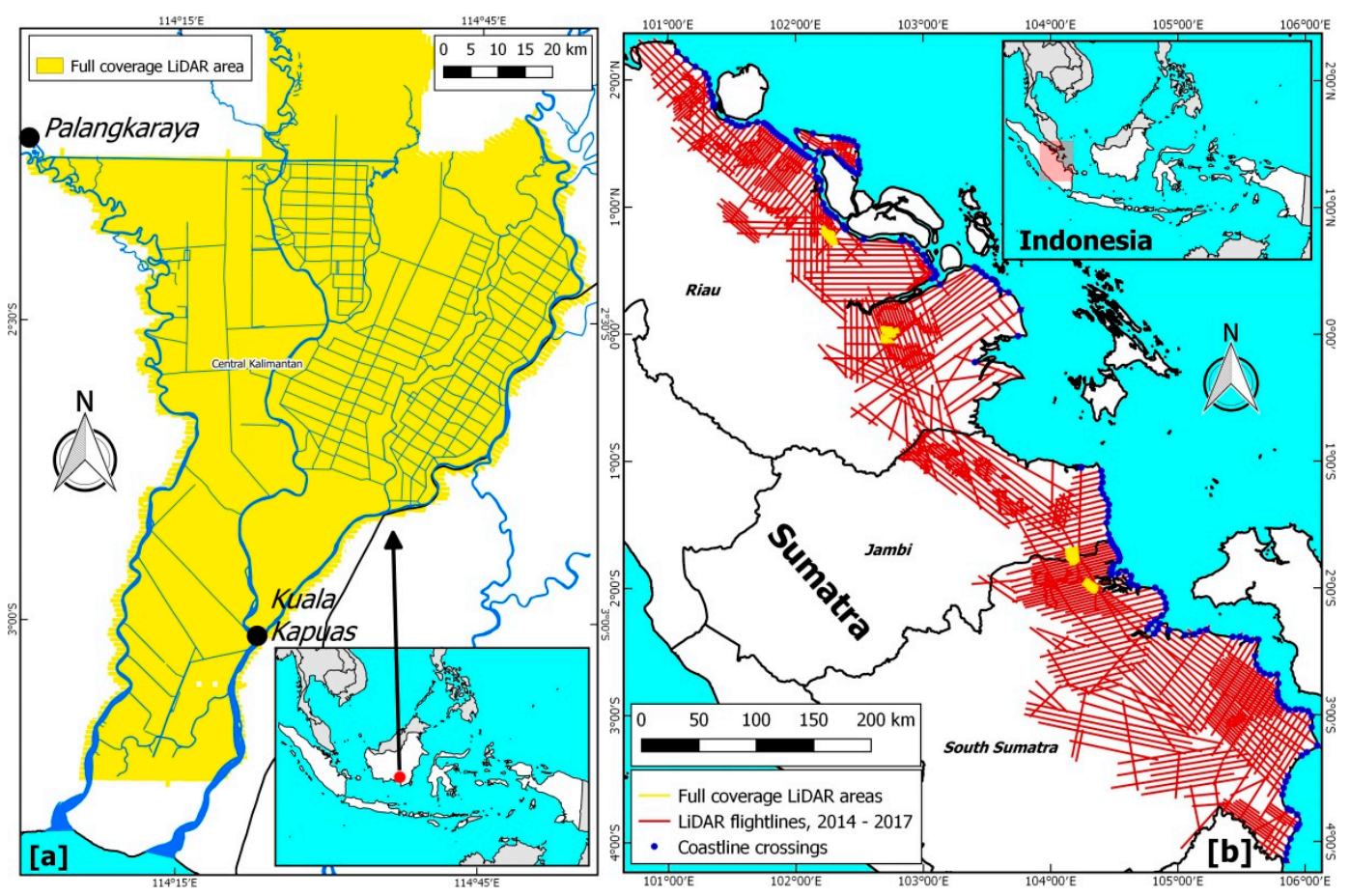

Figure 1. LiDAR coverage over the Indonesian Provinces (a) Central Kalimantan and (b) Riau, Jambi, and South Sumatra. Areas of full LiDAR coverage are indicated in yellow, and partial LiDAR coverage is indicated in red. Locations of LiDAR flight coastline crossings used in validation of MSL are indicated with blue dots along the East Sumatra coast (Section 3.3).

The total number of actual flight days over East Sumatra was 105, yielding a total LiDAR coverage strip length of 30,138 km (including overlaps and re-flights). Average flight length per day accounting for downtime due to bad weather, mandatory pilot days off, and aircraft maintenance was 189 $\mathrm{km}$. Total effective LiDAR data coverage in East Sumatra was $1.45 \mathrm{Mha}$, accounting for overlaps and re-flights. The total cost of data acquisition in East Sumatra (including orthophoto processing, mobilization and ground referencing surveys) was 60 USD per flight line $\mathrm{km}$, which is equivalent to approximately $1.5 \mathrm{USD} / \mathrm{h}$ a of actual coverage with a swath width of $687 \mathrm{~m}$, is achieved by flying at 850 $\mathrm{m}$ elevation with a scan angle of 44 degrees. The accuracy report that accompanied the East Sumatra LiDAR data estimated the total vertical accuracy to be $0.050 \mathrm{~m}$, consisting of a vertical MSL referencing accuracy of $0.009 \mathrm{~m}$ RMSE and an average check point survey RMSE of $0.041 \mathrm{~m}$. Mean first return point density of the East Sumatra LiDAR data acquisition was around 7 points $\mathrm{m}^{-2}$.

\subsection{LiDAR Point Cloud Filtering}

The progressive morphological filter algorithm [19] was used to separate ground returns (including water) from overlying vegetation returns (Figure 2). Earlier studies have found that this algorithm performs well in lowland areas and performs similar or better compared to other filtering algorithms $[20,21]$. The filter creates a maximum elevation grid, derived from progressively increasing the allowed elevation per radius from a minimum elevation point in each cell. A comparison of each individual data point with maximum elevation grid determines whether it is classified as 'terrain' or 'above-terrain'. While the ground classification excluded large areas of open water it cannot be excluded that small inundated areas were classified as ground. 
A

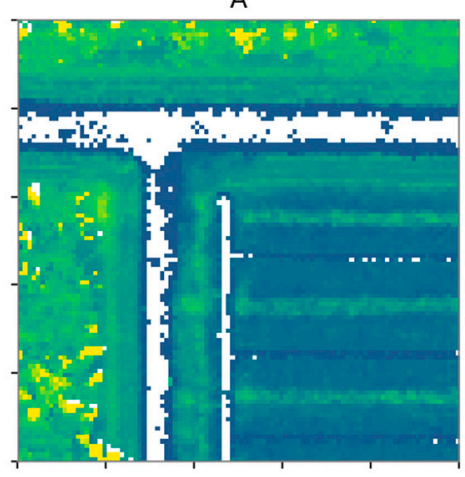

B

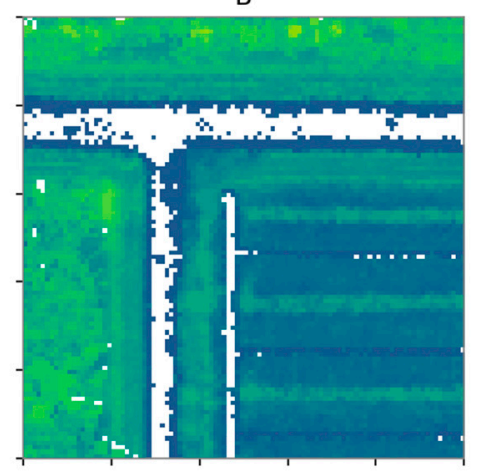

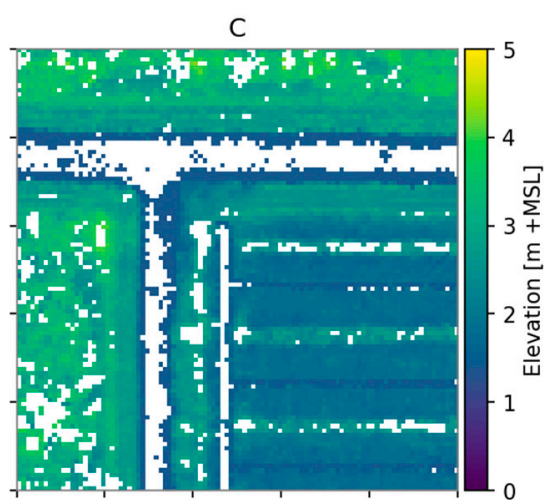

Figure 2. Ground filtering process illustrated for a $100 \times 100 \mathrm{~m}$ area in South Sumatra Province: (A) Minimum elevation raster of all points in a $1 \mathrm{~m}$ grid cell. (B) Applying the progressive morphological filter (pmf) to [A] results in a maximum allowed elevation grid, as shown in (B). (C) Ground surface DTM based on all cell points in (A) below (B). White cells are no data areas.

After the point cloud classification, a DTM at $1 \mathrm{~m}$ resolution was produced by determining the minimum elevation of all ground returns within the $1 \mathrm{~m}$ grid. Subsequently, a $100 \mathrm{~m}$ DTM was produced by determining the median of the $1 \mathrm{~m} \mathrm{DTM}$, to remove site microtopography, with elevation differences exceeding $0.5 \mathrm{~m}$ within a few meters being commonly observed in the field to be common in all types of peatland, as has been reported for peat swamp forest [22]. In mineral soil lowlands, which we find to occur below $\sim 3 \mathrm{~m}+\mathrm{MSL}$ in the East Sumatra study area, microtopography is usually limited to less than $0.25 \mathrm{~m}$.

The steps described above have been coded in the Julia programming language [23] using several open source libraries [24]. The full code is available [25].

\subsection{Interpolation Between LiDAR Data Strips}

Contour lines were drawn manually between the individual LiDAR strip DTMs, following an agreed protocol, by trained geographers who understood the genesis and morphology of lowland landscapes including such features as peat domes, river levees, backswamps, and also subsidence ridges where part of a peatland had recently dropped due to peat oxidation and compaction after drainage, relative to its surroundings (Figure 3). Recent cloud-free optical satellite imagery (Landsat-8 and Sentinel-2) was used in the background during contour line drawing, to help identify such features. In the most complex areas, especially where drainage induced peatland subsidence was a factor, two geographers drafted contour lines and differences were identified and corrected.

Contours in most landscapes were drawn at $0.5 \mathrm{~m}$ intervals, except in some areas of specific interest such as tree plantations and river levees where $0.25 \mathrm{~m}$ intervals were applied. The total length of contour lines drawn over East Sumatra for this study was $61,300 \mathrm{~km}$, over 5.7 Mha of land between strips, which took one person year of work at a cost of approximately 50 kUSD (excluding training, trials and supervision) which is a minor fraction of LiDAR data acquisition costs. 

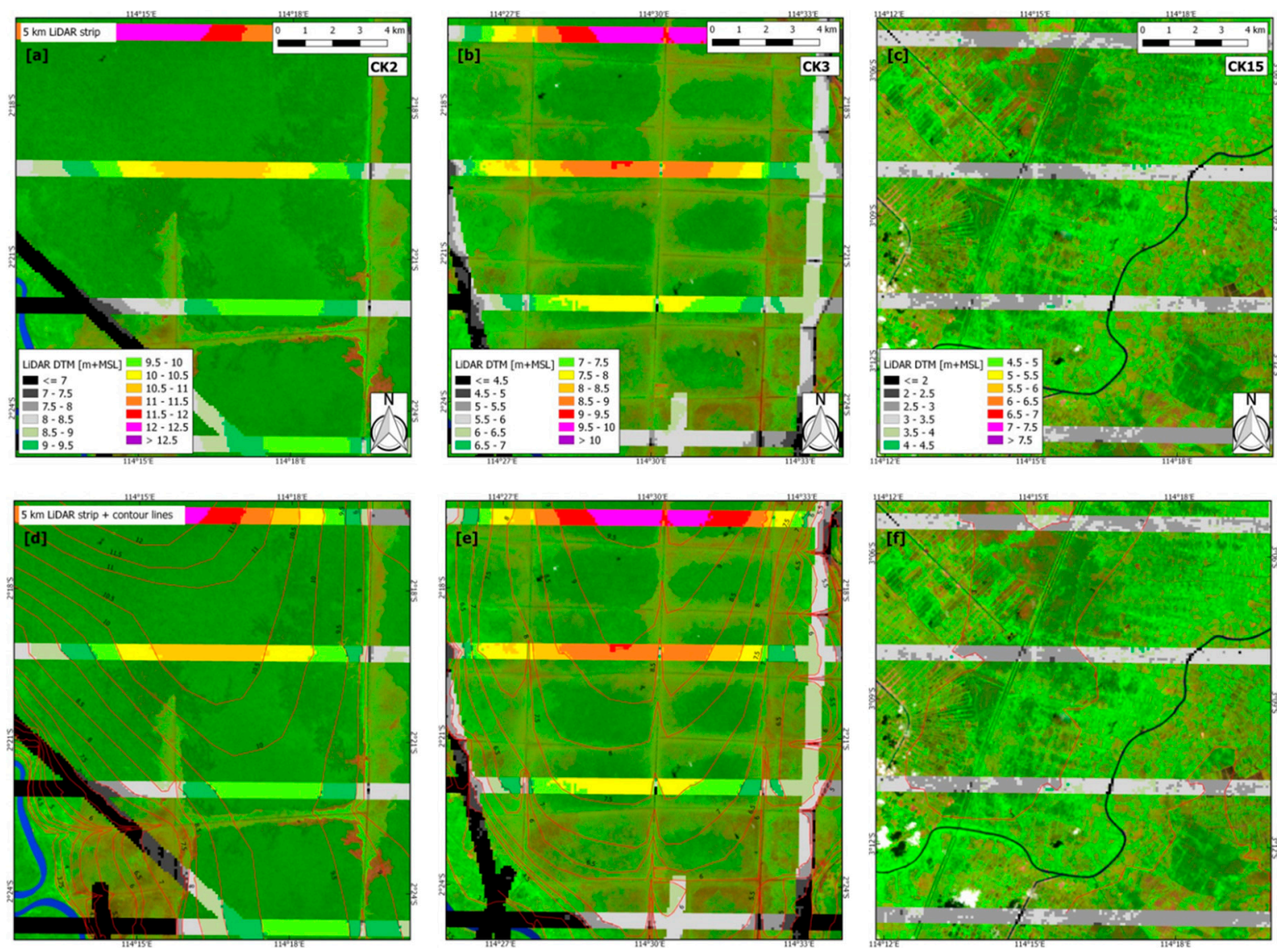

Figure 3. Examples of contour lines manually drawn in different situations. (a,d) a relatively intact peat dome (CK2), (b,e) a drained peat dome with subsidence (CK3), (c,f) a mineral soil area without much topography (CK15). Area codes with location are shown in Figure 4. (a-c) Five kilometer LiDAR strips (in this example simulated from the full coverage DTM shown in Figure 4) and (d-f) adding contour lines. In the background Landsat- 8 composite image of 3 August 2015. For each of the examples the same legend color scheme was used but with different elevation intervals.

A full coverage DTM was then created by Inverse Distance Weighting (IDW) Interpolation between the LiDAR strip DTMs and contour lines. The GDAL rasterize (https://www.gdal.org/gdal_rasterize. $\mathrm{html}$ ) algorithm was used for rasterizing contour lines at $100 \mathrm{~m}$ spatial resolution, after which they were merged with the strip DTM where the latter takes prevalence. The implemented IDW method only takes into account the nearest raster cells that have a value, or contour lines, in all directions. This interpolation method is applicable in areas where landscape features are large-scale and gradual, as is usually the case in lowlands. Local small-scale features with higher slopes will not be represented in the interpolated DTM, for instance along drainage canals where extreme subsidence has occurred over narrow zones, and where no contour lines could be drawn due to lack of geographical information. 


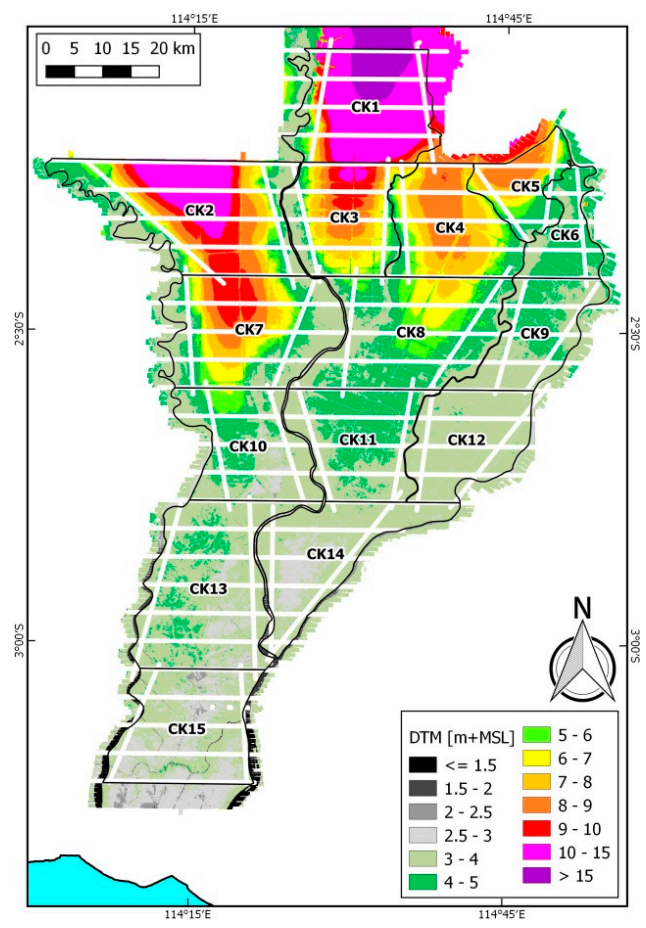

Figure 4. LiDAR DTM covering the Ex Mega Rice Project area in Central Kalimantan and location of 15 areas (enclosed by black lines) where DTM accuracy was tested using different flight line intervals (2.5, 5 , and $10 \mathrm{~km}$ ). General characteristics for each of these areas are provided in Table 1. Shown as well is the partial LiDAR data coverage for $5 \mathrm{~km}$ flight line intervals plus main rivers (white lines) used to create the interpolated DTM.

\subsection{Validation of Interpolated DTM}

The accuracy of the DTM created by interpolation between partial LiDAR coverage and contour lines was tested for the full coverage lowland area in Central Kalimantan at $100 \mathrm{~m}$ spatial resolution. The $500 \mathrm{~m}$ wide 'LiDAR data strips' were simulated that would have resulted from partial coverage LiDAR data acquisition along East-West flight lines at intervals of 2.5, 5, or $10 \mathrm{~km}$ spacing plus additional flight lines along main rivers (Figure 4). Contour lines were drawn separately for each of these simulated flight intervals.

The full coverage area was divided into 15 smaller areas $(17,000-62,000 \mathrm{ha})$ to represent a variety of different land cover and drainage conditions ranging from relatively undrained peat swamp forest, mixed areas of largely deforested and burnt peatland, and agriculture on mineral lowland soil (Figure 4; Table 1).

The interpolated DTMs at 2.5, 5, and $10 \mathrm{~km}$ intervals were then compared with the full coverage DTM, and differences were determined. To evaluate the effect of the contour lines we also compared an interpolated DTM using only the LiDAR data.

\section{Results}

\subsection{Validation of Interpolated DTM Accuracy for Central Kalimantan}

Differences between the $100 \mathrm{~m}$ Central Kalimantan EMRP full coverage LiDAR DTM (Figure 4), and the interpolated DTMs from simulated flight line 'data strips' at 2.5, 5, and $10 \mathrm{~km}$ intervals and associated contour lines are, averaged over the 15 test areas, within $0.5 \mathrm{~m}$ for $96.4 \%, 94.5 \%$, and $87.7 \%$ of the total area, respectively (Table 1). The differences were slightly smaller for the peat-dominated areas compared to the mineral soil areas, except for the $10 \mathrm{~km}$ flight line intervals (Table 1).

DTM differences are shown in Figure 5. Positive differences (interpolated DTM higher than full coverage DTM) are most common and occur mostly along drainage canals where subsidence rates are highest and least predictable. 
Table 1. LiDAR interpolated DTM at $100 \mathrm{~m}$ spatial resolution validation results for the individual 15 test areas in Central Kalimantan (Figure 4) with flight line spacing at 2.5, 5, and $10 \mathrm{~km}$, respectively. Presented are average elevation differences between full coverage and interpolated DTM per test area as well as RMSE and the area percentage differences within ranges $0-0.25 \mathrm{~m}, 0-0.50 \mathrm{~m}$, and $0-1.0 \mathrm{~m}$. Average accuracy is also presented for $500 \mathrm{~m}$ spatial resolution interpolated DTMs, and separately for the result without using manual contour lines in the interpolation at $100 \mathrm{~m}$ spatial resolution. General characteristics for each of the 15 areas are provided, where dominant land cover is based on 2011 land cover map [26], peat occurrence is based on [27], simplified as deep ( $>3 \mathrm{~m})$, and shallow ( $<3 \mathrm{~m})$ peat, and drainage density is based on visual interpretation of Landsat composite imagery acquired at the time of LiDAR data acquisition.

\begin{tabular}{|c|c|c|c|c|c|c|c|c|c|c|c|c|c|c|c|c|c|c|c|}
\hline & & & & & & & $2.5 \mathrm{~km}$ & & & & & $5 \mathrm{~km}$ & & & & & $10 \mathrm{~km}$ & & \\
\hline AreaId & Area [ha] & $\begin{array}{l}\text { Dominant Land } \\
\text { Cover }\end{array}$ & Peat & $\begin{array}{c}\text { Drainage } \\
\text { Density }\end{array}$ & $\begin{array}{c}\text { Avg. } \\
\text { Difference } \\
{[\mathrm{m}]}\end{array}$ & $\begin{array}{c}\text { RMSE } \\
{[\mathrm{m}]}\end{array}$ & $\begin{array}{c}0-0.25 \mathrm{~m} \\
{[\%]}\end{array}$ & $\begin{array}{c}0-0.50 \mathrm{~m} \\
{[\%]}\end{array}$ & $\begin{array}{c}0-1.0 \mathrm{~m} \\
{[\%]}\end{array}$ & $\begin{array}{c}\text { Avg. } \\
\text { Difference } \\
{[\mathrm{m}]}\end{array}$ & RMSE [m] & $\begin{array}{c}0-0.25 \mathrm{~m} \\
{[\%]}\end{array}$ & $\begin{array}{c}0-0.50 \mathrm{~m} \\
{[\%]}\end{array}$ & $\begin{array}{c}0-1.0 \mathrm{~m} \\
{[\%]}\end{array}$ & $\begin{array}{c}\text { Avg. } \\
\text { Difference } \\
{[\mathrm{m}]}\end{array}$ & $\begin{array}{c}\text { RMSE } \\
{[\mathrm{m}]}\end{array}$ & $\begin{array}{c}0-0.25 \mathrm{~m} \\
{[\%]}\end{array}$ & $\begin{array}{c}0-0.50 \mathrm{~m} \\
{[\%]}\end{array}$ & $\begin{array}{c}0-1.0 \mathrm{~m} \\
{[\%]}\end{array}$ \\
\hline CK1 & 45626 & $\begin{array}{l}\text { peat swamp } \\
\text { forest }\end{array}$ & deep & low & -0.04 & 0.36 & 94.7 & 97.6 & 98.6 & -0.04 & 0.39 & 87.7 & 95.5 & 98.3 & 0.00 & 0.43 & 69.5 & 88.3 & 97.5 \\
\hline CK2 & 62097 & $\begin{array}{l}\text { peat swamp } \\
\text { forest }\end{array}$ & deep & moderate & -0.01 & 0.17 & 91.6 & 97.5 & 99.6 & 0.00 & 0.22 & 86.0 & 95.8 & 99.3 & 0.00 & 0.33 & 70.0 & 88.3 & 98.3 \\
\hline СK3 & 36670 & $\begin{array}{l}\text { swamp } \\
\text { shrubland }\end{array}$ & deep & high & 0.02 & 0.24 & 87.5 & 95.6 & 98.7 & 0.01 & 0.27 & 82.1 & 94.4 & 98.5 & 0.01 & 0.30 & 77.2 & 93.4 & 98.2 \\
\hline CK4 & 37239 & $\begin{array}{l}\text { swamp } \\
\text { shrubland }\end{array}$ & deep & moderate & -0.02 & 0.15 & 92.8 & 98.3 & 99.9 & -0.04 & 0.22 & 84.0 & 96.3 & 99.3 & -0.18 & 0.45 & 49.1 & 74.4 & 97.1 \\
\hline CK5 & 19254 & $\begin{array}{l}\text { swamp } \\
\text { shrubland }\end{array}$ & deep & low & -0.02 & 0.21 & 85.6 & 95.7 & 99.5 & -0.01 & 0.24 & 80.3 & 93.2 & 99.6 & 0.01 & 0.39 & 64.5 & 84.1 & 97.6 \\
\hline CK6 & 16937 & shrubland & $\begin{array}{l}\text { shallow } \\
\text { pockets }\end{array}$ & high & 0.01 & 0.19 & 87.4 & 96.7 & 99.7 & 0.00 & 0.23 & 79.1 & 95.6 & 99.6 & -0.02 & 0.30 & 63.0 & 91.8 & 99.2 \\
\hline CK7 & 55205 & $\begin{array}{c}\text { swamp } \\
\text { shrubland }\end{array}$ & deep & high & 0.00 & 0.18 & 89.9 & 97.1 & 99.5 & 0.00 & 0.23 & 84.7 & 96.3 & 99.3 & -0.12 & 0.49 & 66.5 & 84.6 & 93.2 \\
\hline СК8 & 57697 & $\begin{array}{l}\text { swamp } \\
\text { shrubland }\end{array}$ & deep & high & 0.00 & 0.22 & 84.3 & 95.5 & 99.4 & -0.01 & 0.29 & 74.1 & 91.2 & 98.9 & 0.02 & 0.41 & 56.5 & 79.5 & 97.0 \\
\hline СК9 & 29455 & rice land & $\begin{array}{l}\text { shallow } \\
\text { pockets }\end{array}$ & high & -0.02 & 0.14 & 93.2 & 98.5 & 100.0 & 0.00 & 0.18 & 88.3 & 97.5 & 99.9 & 0.02 & 0.20 & 83.8 & 96.3 & 99.9 \\
\hline СК10 & 37751 & $\begin{array}{l}\text { swamp } \\
\text { shrubland }\end{array}$ & $\begin{array}{l}\text { deep+shallow } \\
\text { pockets }\end{array}$ & high & -0.05 & 0.23 & 85.3 & 95.0 & 99.4 & 0.04 & 0.27 & 76.6 & 92.0 & 99.6 & 0.21 & 0.45 & 58.7 & 79.0 & 94.8 \\
\hline CK11 & 39050 & rice land & $\begin{array}{l}\text { shallow } \\
\text { pockets }\end{array}$ & high & 0.00 & 0.20 & 85.7 & 96.1 & 99.6 & -0.05 & 0.24 & 77.4 & 93.9 & 99.7 & -0.09 & 0.28 & 70.0 & 91.2 & 99.7 \\
\hline CK12 & 33751 & rice land & $\begin{array}{l}\text { shallow } \\
\text { pockets }\end{array}$ & high & 0.00 & 0.16 & 93.3 & 97.4 & 99.9 & 0.00 & 0.17 & 91.5 & 97.1 & 99.9 & 0.05 & 0.19 & 90.3 & 96.5 & 99.8 \\
\hline CK13 & 61033 & rice land & $\begin{array}{l}\text { shallow } \\
\text { pockets }\end{array}$ & high & -0.03 & 0.23 & 79.8 & 94.7 & 99.6 & -0.03 & 0.27 & 73.1 & 92.3 & 99.6 & -0.07 & 0.31 & 67.1 & 89.0 & 99.1 \\
\hline CK14 & 39294 & rice land & no & high & -0.03 & 0.16 & 90.3 & 98.1 & 99.9 & -0.02 & 0.17 & 89.1 & 97.9 & 99.8 & 0.03 & 0.20 & 83.0 & 96.7 & 99.8 \\
\hline CK15 & 44892 & rice land & $\begin{array}{l}\text { shallow } \\
\text { pockets }\end{array}$ & high & -0.02 & 0.25 & 81.7 & 93.9 & 99.1 & -0.01 & 0.30 & 73.8 & 91.3 & 98.6 & -0.09 & 0.32 & 71.1 & 89.3 & 98.1 \\
\hline \multicolumn{5}{|c|}{ Avg. (mostly peat, CK1-5, CK7; 100 m) } & -0.01 & 0.23 & 90.9 & 97.1 & 99.3 & -0.01 & 0.27 & 84.7 & 95.5 & 99.0 & -0.05 & 0.41 & 66.7 & 85.9 & 96.8 \\
\hline \multicolumn{5}{|c|}{ Avg. (mostly mineral soil, CK6, CK8-15; 100 m) } & -0.02 & 0.21 & 85.8 & 95.9 & 99.6 & -0.01 & 0.25 & 79.2 & 93.8 & 99.4 & 0.00 & 0.32 & 70.4 & 89.0 & 98.5 \\
\hline \multicolumn{5}{|c|}{ Avg. (all; 100 m) } & -0.01 & 0.22 & 88.0 & 96.4 & 99.5 & -0.01 & 0.26 & 81.5 & 94.5 & 99.3 & -0.02 & 0.36 & 68.9 & 87.7 & 97.8 \\
\hline \multicolumn{5}{|c|}{ Avg. (all; $500 \mathrm{~m})$} & -0.02 & 0.29 & 79.4 & 93.5 & 98.9 & -0.01 & 0.31 & 74.1 & 92.0 & 98.8 & -0.02 & 0.40 & 63.9 & 85.7 & 97.2 \\
\hline \multicolumn{5}{|c|}{$\begin{array}{r}\text { Avg. (all; } 100 \mathrm{~m} \text {; automatic interpolation with only LiDAR strip } \\
\text { data) }\end{array}$} & -0.01 & 0.22 & 86.6 & 95.9 & 99.4 & -0.05 & 0.33 & 68.7 & 88.9 & 98.8 & -0.14 & 0.56 & 56.2 & 74.3 & 90.4 \\
\hline
\end{tabular}



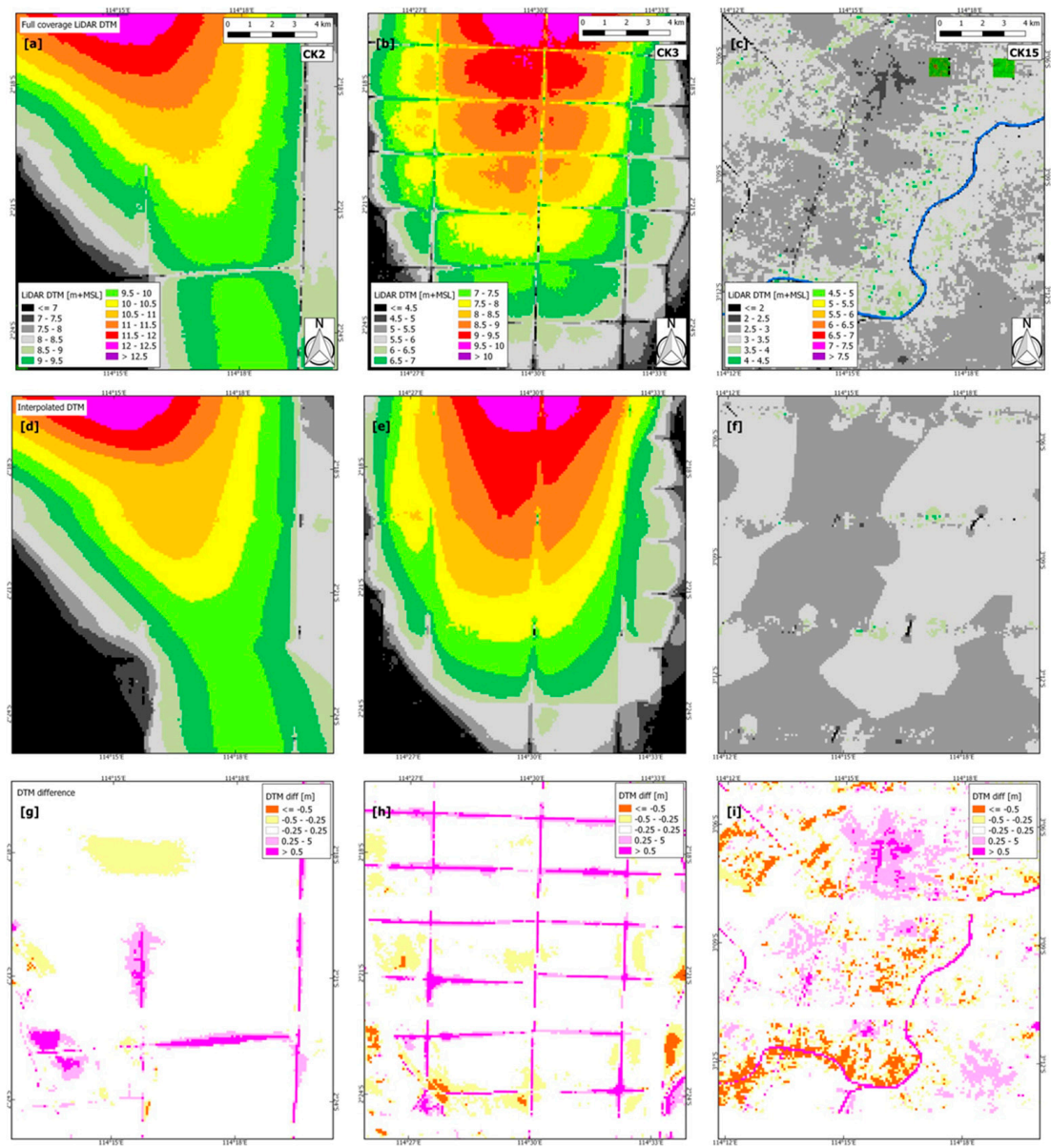

Figure 5. (a-c) Full coverage LiDAR DTM, and (d-f) interpolated DTM from simulated $5 \mathrm{~km}$ flight line intervals plus main rivers and contour lines, and $(\mathrm{g}-\mathbf{i})$ the difference between interpolated and full coverage LiDAR DTM, for (from left to right) areas CK2, CK3, and CK15 (see also Figure 3). Note that for the DTMs of the three different areas the same legend color scheme was used but with different elevation intervals.

As shown in Figure 6, differences are slightly skewed towards the negative (i.e., interpolated DTM are lower than full coverage DTM), resulting in an average underestimation error of $-0.01,-0.01$, and $-0.02 \mathrm{~m}$ in the validation area and RMSE of $0.22,0.26$, and $0.36 \mathrm{~m}$, for flight line spacing at 2.5, 5, and $10 \mathrm{~km}$ intervals, respectively (Table 1). A lower resolution DTM of $500 \mathrm{~m}$ increases the RMSE by 0.04 to $0.07 \mathrm{~m}$ while the area where elevation differences are within $0.5 \mathrm{~m}$ is reduced by $2.0-3.0 \%$ compared to the $100 \mathrm{~m}$ resolution DTM (Table 1).

The evaluation of the effect of the interpolated DTM with or without the use of contour lines shows that the RMSE is the same at a $2.5 \mathrm{~km}$ LiDAR flight line spacing but is $0.07-0.20 \mathrm{~m}$ lower in case LiDAR flight line spacing is 5 and $10 \mathrm{~km}$, respectively. At the 2.5, 5, and $10 \mathrm{~km}$ flight line spacing, respectively, $96.4 \%, 94.5 \%$, and $87.7 \%$ of the interpolated DTM is within $0.5 \mathrm{~m}$ from the full coverage $100 \mathrm{~m}$ DTM when manual contour lines are applied, whereas this is $95.9 \%, 88.9 \%$, and $52.6 \%$ without applying contour lines. This result confirms that in case LiDAR is acquired at 5 or $10 \mathrm{~km}$ flight line intervals, adding contour lines greatly improves overall DTM accuracy, but the effect is less substantial where $2.5 \mathrm{~km}$ intervals are applied. 


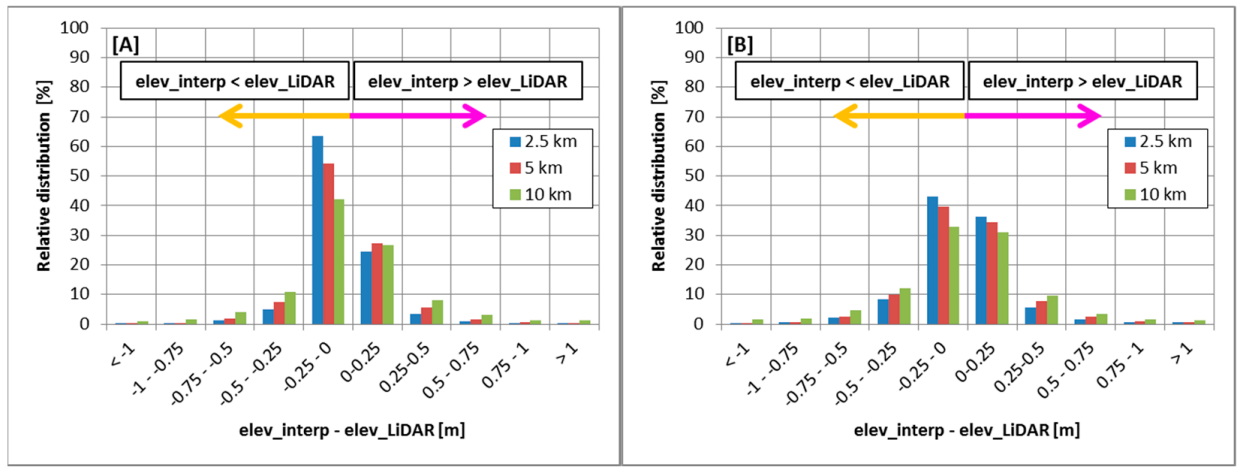

Figure 6. Distribution of DTM differences for all 15 validation areas together for $2.5 \mathrm{~km}, 5 \mathrm{~km}$, and 10 km flight line intervals for (A) $100 \mathrm{~m}$ and (B) $500 \mathrm{~m}$ spatial resolution interpolated DTMs (elev_interp). The $500 \mathrm{~m}$ interpolated DTM is compared with the $100 \mathrm{~m}$ full coverage DTM (elev_LiDAR).

\subsection{Extent of the East Sumatra Lowland DTM}

The DTM coverage of 7.1 Mha in the East Sumatra provinces of Riau, Jambi, and South Sumatra (Figure 7) constitutes $80.4 \%$ of the lowland area in these provinces, and $63.6 \%$ of the lowland area in Sumatra as a whole (11.2 Mha), as determined from the lowland boundary determined by [28]. The DTM covers 4.5 Mha of peatland according to the peat map published by the Indonesian Ministry of Agriculture in 2011 [27], which is $62.7 \%$ of the total Sumatra peatland coverage of 6.6 Mha according to the same source.

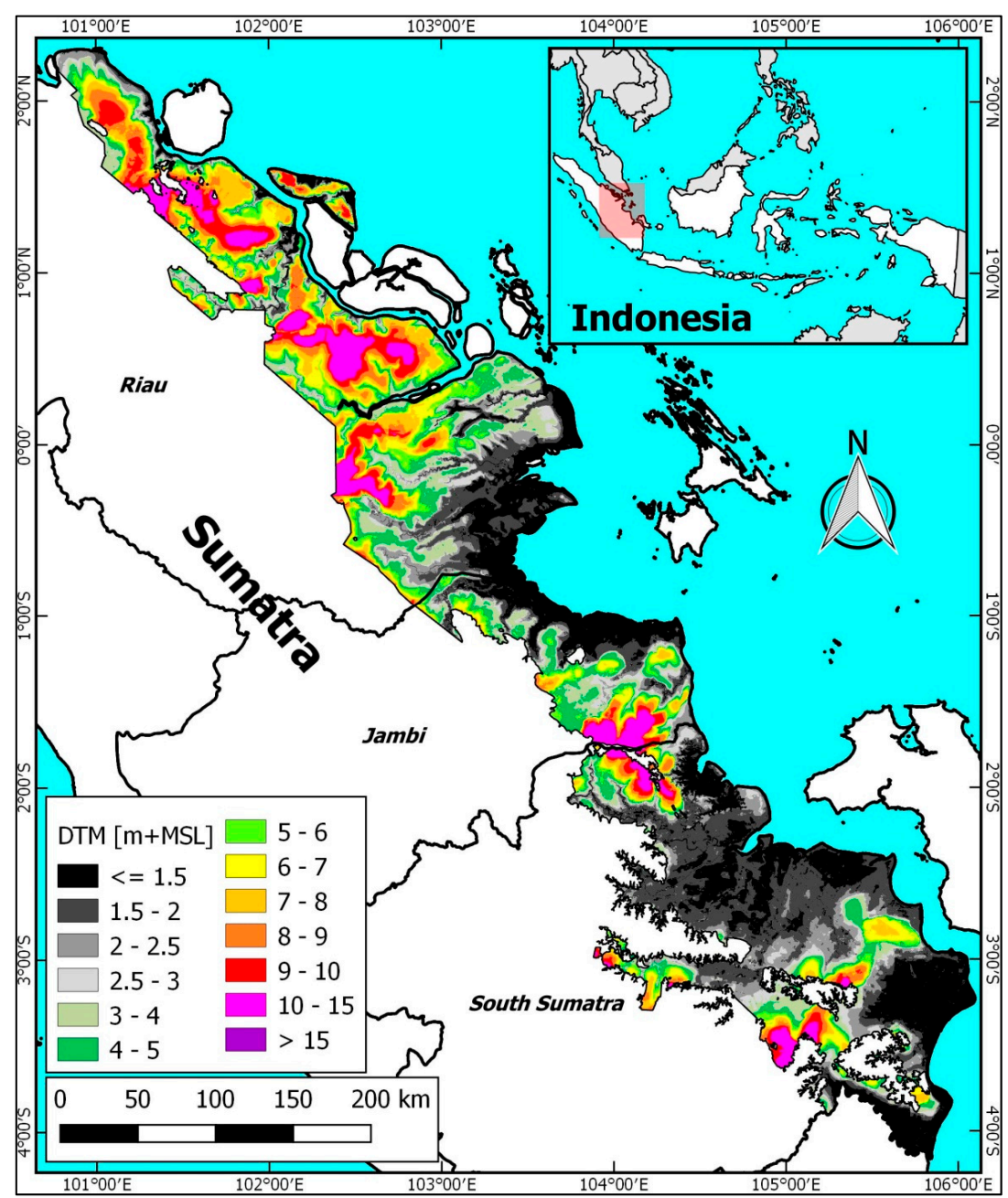

Figure 7. East Sumatra lowland DTM as generated from partial LiDAR data and contour lines. 


\subsection{Referencing to Mean Sea Level}

Benchmark elevations relative to mean sea level (MSL) in SE Asia are known to be sometimes inaccurate, because referencing was done mostly in the 1980s when differential GPS (DGPS) was not yet common and tidal records were mostly short and inaccurate. Moreover, some benchmarks on soft soils are known to have subsided, and recent sea level rise and land surface subsidence has not yet been corrected for. Therefore, referencing of the East Sumatra DTM presented here was validated by determining actual sea water levels measured by LiDAR where flight lines crossed the sea, totaling 197 locations along the coastlines of Riau, Jambi, and South Sumatra (Figure 1). While each individual sea water surface level measurement represents an instantaneous and local tidal level, not MSL, the full dataset represents conditions over a long time period and a large area and may be assumed to represent a measure of the full tidal range. This is also evident from the range of values, roughly between 1.0 and $1.5 \mathrm{~m}+\mathrm{MSL}$ and 1.0 and $1.5 \mathrm{~m}-\mathrm{MSL}$, which corresponds with the known tidal range of around 3.0 to $4.0 \mathrm{~m}$ along most of the Sumatra coastline. Therefore, the average over all sea water level measurements by LiDAR would be expected to be close to actual MSL, providing an alternative reference level to benchmarks.

The average sea water surface level as assessed from the LiDAR measurements crossing the coast was $-0.08 \mathrm{~m}( \pm 0.72 \mathrm{~m} \mathrm{std})$ (Figure 8$)$. This difference is considered well within the margin of error of both LiDAR measurements and benchmark referencing to MSL. We, therefore, conclude that the DTM is accurately referenced to MSL.

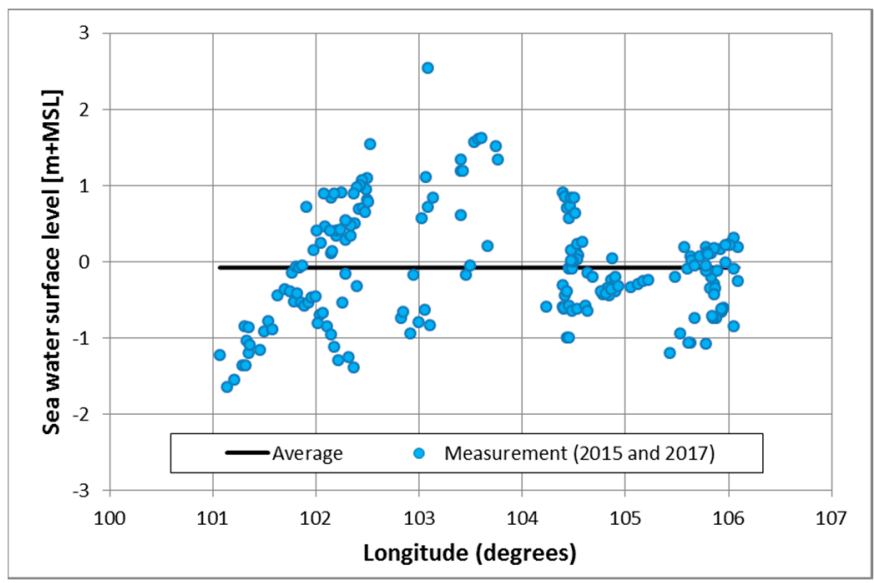

Figure 8. Instantaneous Sea water surface level $(n=197)$ as measured by LiDAR during the 2015 and 2017 campaigns along the East Sumatra coastline. Locations of LiDAR flight line coastline crossings are shown in Figure 1.

\section{Discussion}

\subsection{Accuracy of the Interpolated Lowland DTM}

We have demonstrated the interpolated DTM for Central Kalimantan at $100 \mathrm{~m}$ spatial resolution to be accurate within $0.5 \mathrm{~m}$ for $96.5 \%, 94.7 \%$, and $88.2 \%$ of the area for flight lines at $2.5,5$, and $10 \mathrm{~km}$ intervals, i.e., for land that is within $0.0-1.0 \mathrm{~km}, 1.0-2.5 \mathrm{~km}$, and 2.5-5.0 km from LiDAR data strips $500 \mathrm{~m}$ wide. In areas where flight lines are more than $10 \mathrm{~km}$ apart, accuracy is lower but not quantified. The overall accuracy of the DTM is the sum of the interpolation error (ranging between 0.22 and $0.36 \mathrm{~m}$ RMSE; Table 1), the vertical referencing error (0.05 m RMSE; Section 2.1) and the (vegetation) filtering error. The latter was not assessed in this study but is estimated from the literature to be within $0.20 \mathrm{~m}$ [29], whereby the error is expected to be highest in peatland areas cleared of forest and covered with dense ferns, followed by peat swamp forest with intact microtopography. Therefore, the overall vertical accuracy of the DTM is estimated to be between 0.25 and $0.61 \mathrm{~m}$. 
When interpreting the level of accuracy, it must be noted that in peatlands, the land surface is not flat but very rough and hummocky, with elevation differences over $0.5 \mathrm{~m}$ being common within a few meters [22]. Moreover, in managed peatland landscapes this microtopography will continuously change with crop harvesting and growing cycles. The question, therefore, is not only whether accuracy well within $0.5 \mathrm{~m}$ is feasible technically, for the full area, but also whether it is necessary for management.

In Figure 9 we show the interpolation distance classes for the East Sumatra DTM with the associated areas within each class presented in Table 2. When applying the DTM in further analyses, the corresponding accuracy levels should be kept in mind. We tested the effect of different geographers drawing manual contour lines in the same area which resulted in a maximum RMSE difference of $0.02 \mathrm{~m}$ for individual areas. We recommend that such accuracy tests are applied as part of the training of the geographers new to the method.

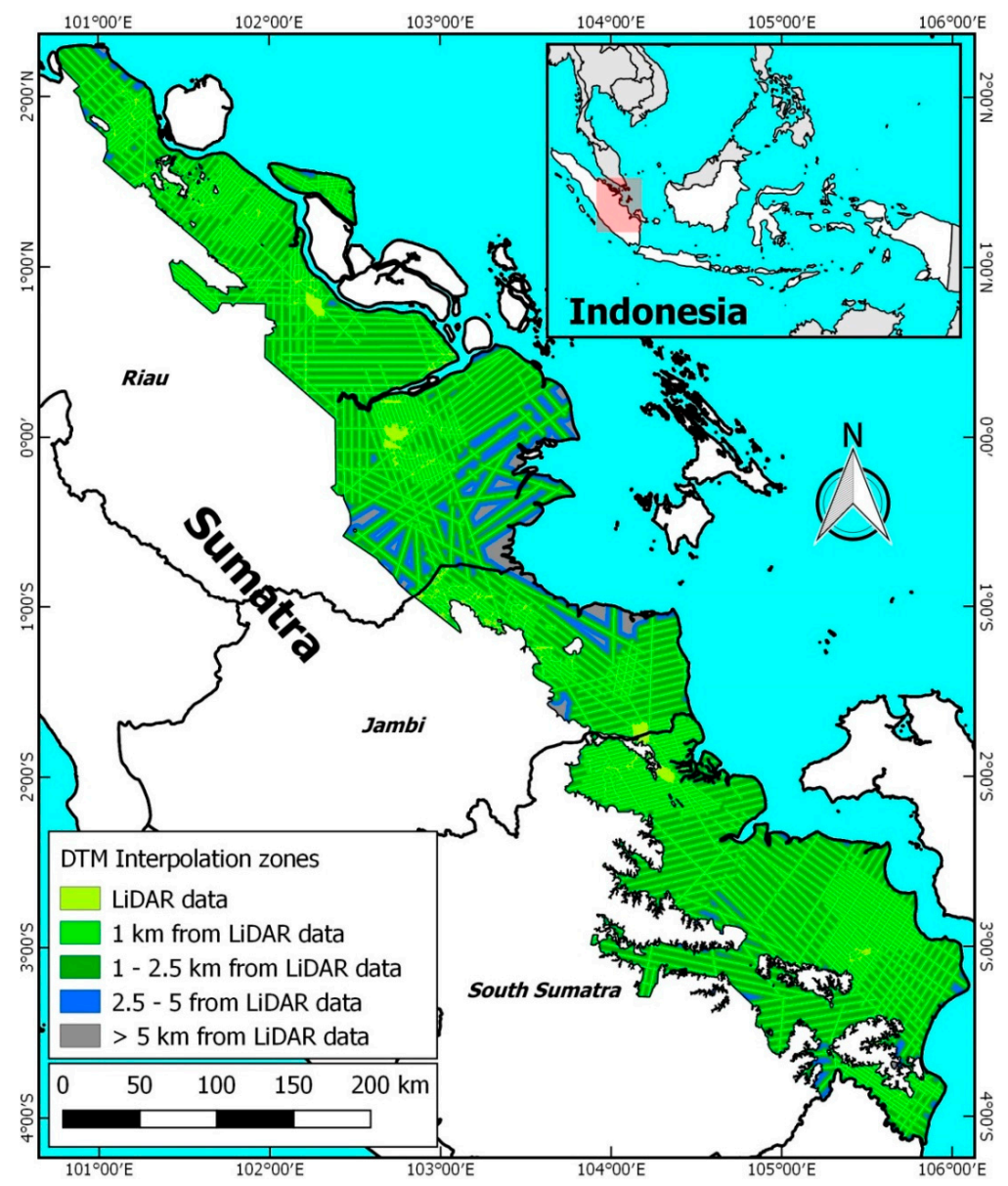

Figure 9. DTM interpolation zones based on interpolation distance between LiDAR 'strips' as presented in Table 1.

Table 2. Areas of the East Sumatra lowland DTM associated with different interpolation distance classes and their estimated vertical accuracy levels.

\begin{tabular}{cccc}
\hline & \multicolumn{2}{c}{ Area } & Estimated RMSE \\
\cline { 2 - 4 } Interpolation Distance Class & {$[$ Mha] } & {$[\%]$} & {$[\mathbf{m}]$} \\
\hline LiDAR data & 1.45 & 20.4 & 0.25 \\
1 km from LiDAR data & 3.31 & 46.4 & $<0.47$ \\
$1-2.5$ km from LiDAR data & 1.87 & 26.2 & $<0.51$ \\
$2.5-5$ km from LiDAR data & 0.37 & 5.2 & $<0.61$ \\
$>5$ km from LiDAR data & 0.13 & 1.8 & $>0.61$ \\
\hline Total & $\mathbf{7 . 1 3}$ & $\mathbf{1 0 0 . 0}$ & $\mathbf{0 . 2 5 - 0 . 6 1}$ \\
\hline
\end{tabular}


The high accuracy of DTM interpolation results (Table 1) is explained by the low surface slopes in these flat lowland areas. Surface slopes in both peatlands and mineral soil areas in the Central Kalimantan lowland test area are generally less than $2 \mathrm{~m} \mathrm{~km}^{-1}$, or less than $20 \mathrm{~cm}$ on average within a $100 \mathrm{~m} \times 100 \mathrm{~m}$ grid cell over which DTM elevation is calculated (Table 3), and below $1.0 \mathrm{~m} \mathrm{~km}^{-1}$ or $10 \mathrm{~cm}$ within a $100 \mathrm{~m} \times 100 \mathrm{~m}$ cell over two-thirds of the area. The steeper slopes in peatlands occur almost exclusively in relatively small areas near canals where land surface subsidence due to drainage has been greatest (Figure 10).

Table 3. Relative area distribution of surface slopes $\left(\mathrm{m} \mathrm{km}^{-1}\right)$ in mineral soils and drained and undrained peatlands in Central Kalimantan as determined from the $100 \mathrm{~m}$ LiDAR full coverage DTM (Figure 4). For test area codes CK1 to CK15 locations, refer to Figure 4.

\begin{tabular}{cccc}
\hline & \multicolumn{3}{c}{ Slope [m km-1] } \\
\cline { 2 - 4 } Lowland Landscape Type & $\mathbf{0 - 0 . 5}$ & $\mathbf{0 - 1}$ & $\mathbf{0 - 2}$ \\
[\%] & {$[\%]$} & {$[\%]$} \\
\hline Undrained peatland (CK1-CK2, CK4-CK5) & 34.7 & 72.2 & 89.4 \\
Drained peatland (CK3, CK6-CK8, CK10) & 36.2 & 65.3 & 86.4 \\
Mineral soils (CK9, CK11-CK15) & 31.1 & 61.2 & 85.7 \\
\hline
\end{tabular}

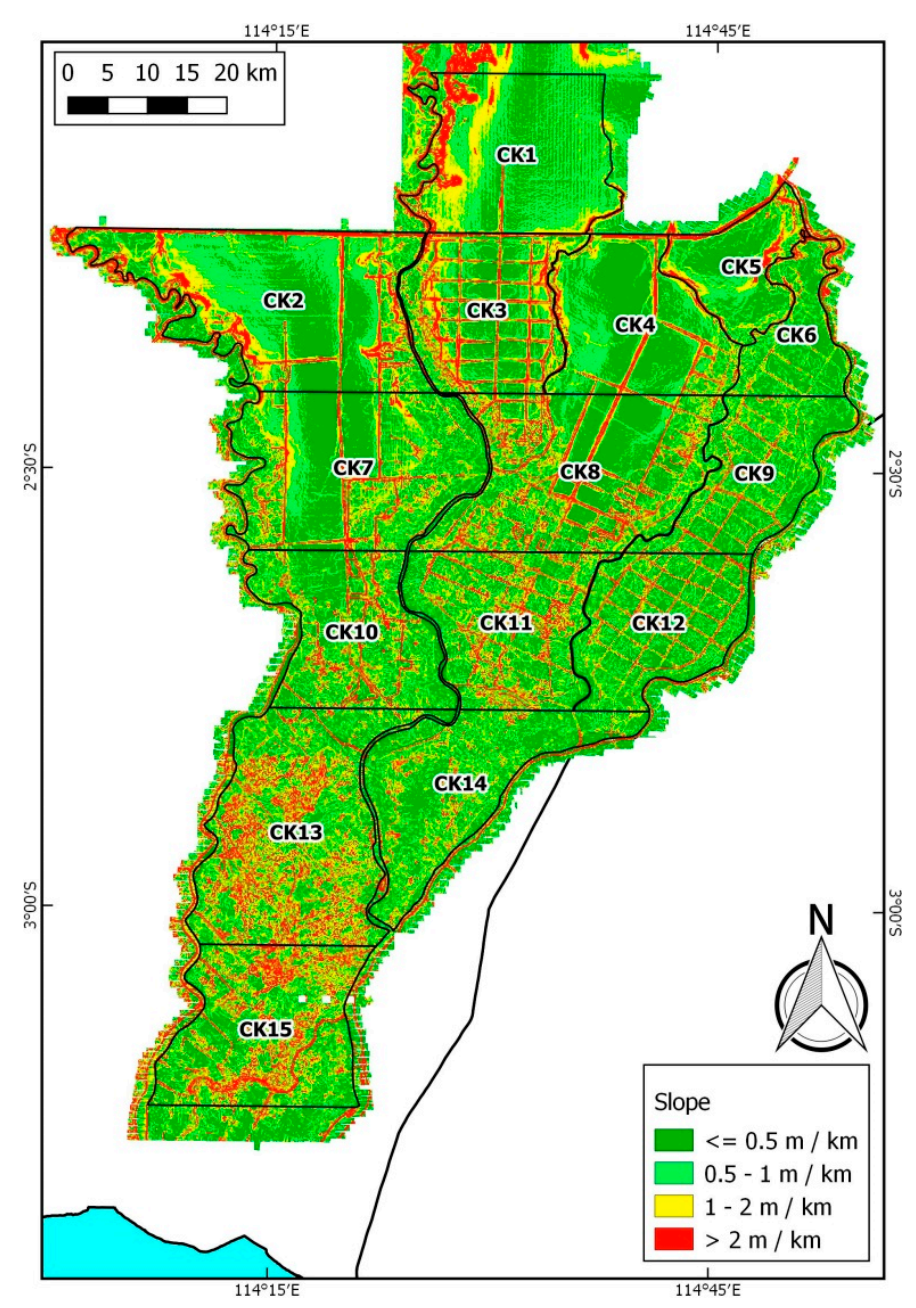

Figure 10. Slope map for LiDAR DTM covering the Ex Mega Rice Project area in Central Kalimantan as presented in Figure 4. 


\subsection{Characteristics of the East Sumatra Lowland DTM}

A three-dimensional model of the East Sumatra coastal lowland DTM (Figure 7) is presented here to demonstrate landscape characteristics (Figure 11). The model shows 2.6 Mha of this DTM, or 36.3\% of the total area, to be below $2 \mathrm{~m}$, i.e., below the approximate highest high tide level. This suggests that large lowland areas are likely to be increasingly flood-prone in the near future as sea level rises, especially where the land surface subsides; this DTM is now applied in flood risk investigations following the approach demonstrated in $[4,5]$.

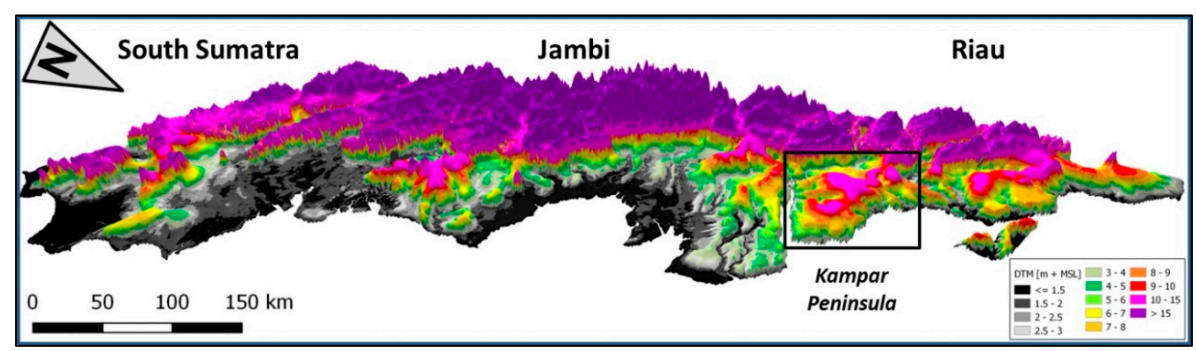

Figure 11. 3D model of the DTM presented in Figure 7. For visualization purposes, this lowland DTM was merged with a SRTM [30] based DTM for upland areas, to show the full landscape; elevations above $10 \mathrm{~m}+$ MSL have sharply reduced vertical scale, by a factor 5 . Indicated as well is the location of Kampar Peninsula, for which a zoomed-in version is presented in Figure 12.

The DTM also reveals smooth 'pillow' shaped domes in most peatland areas in East Sumatra, a landscape pattern that is very typical for peatlands anywhere in the world and that can be used in visually recognizing and mapping peat domes. The Kampar Peninsula for instance, which is known to consist entirely of very deep peat [5,31], can be seen to consist of one contiguous ridge on the north side with connecting ridges extending to the south (Figure 12) making it probably the largest single dome in SE Asia at 700,000 ha.

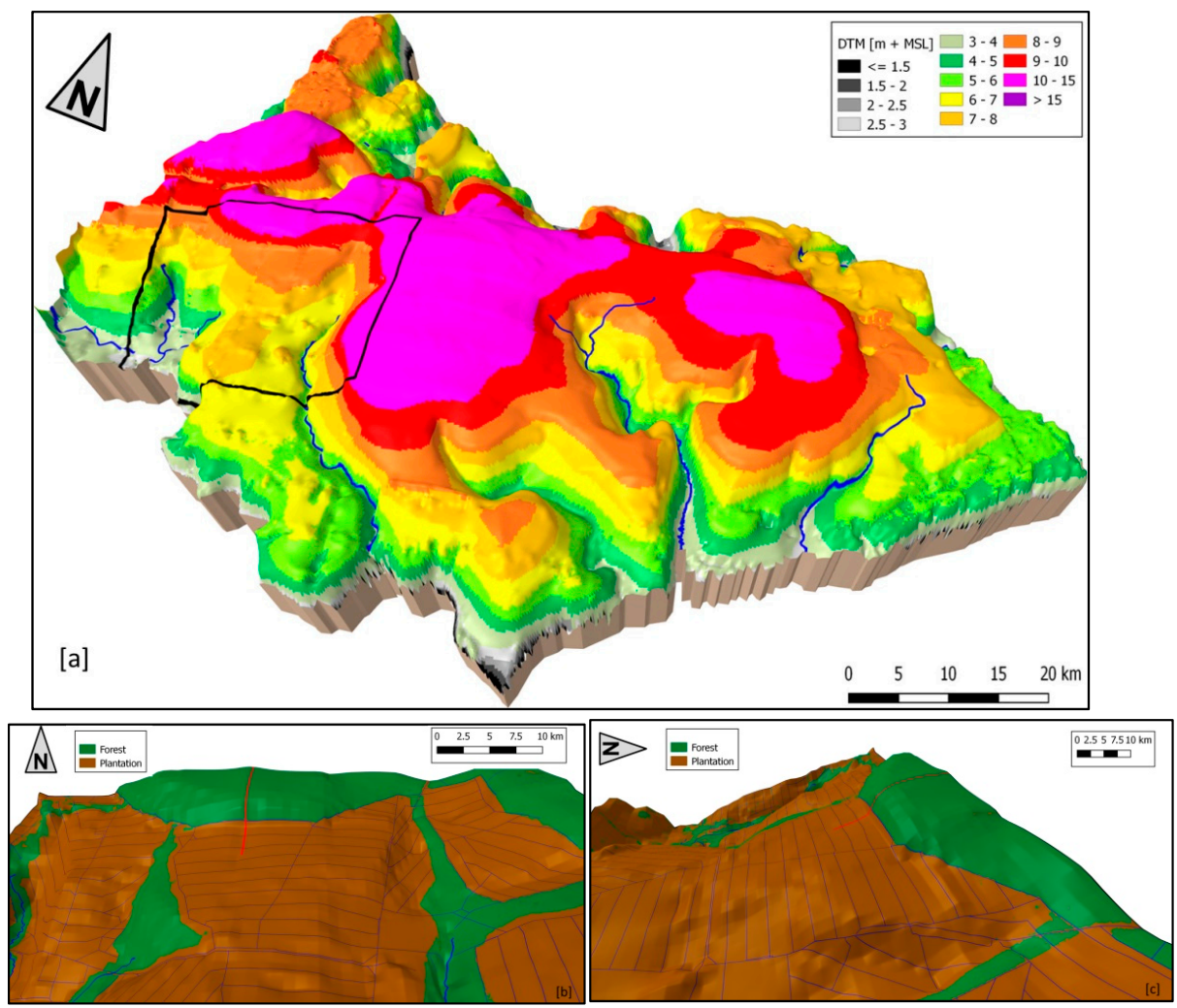

Figure 12. Cont. 


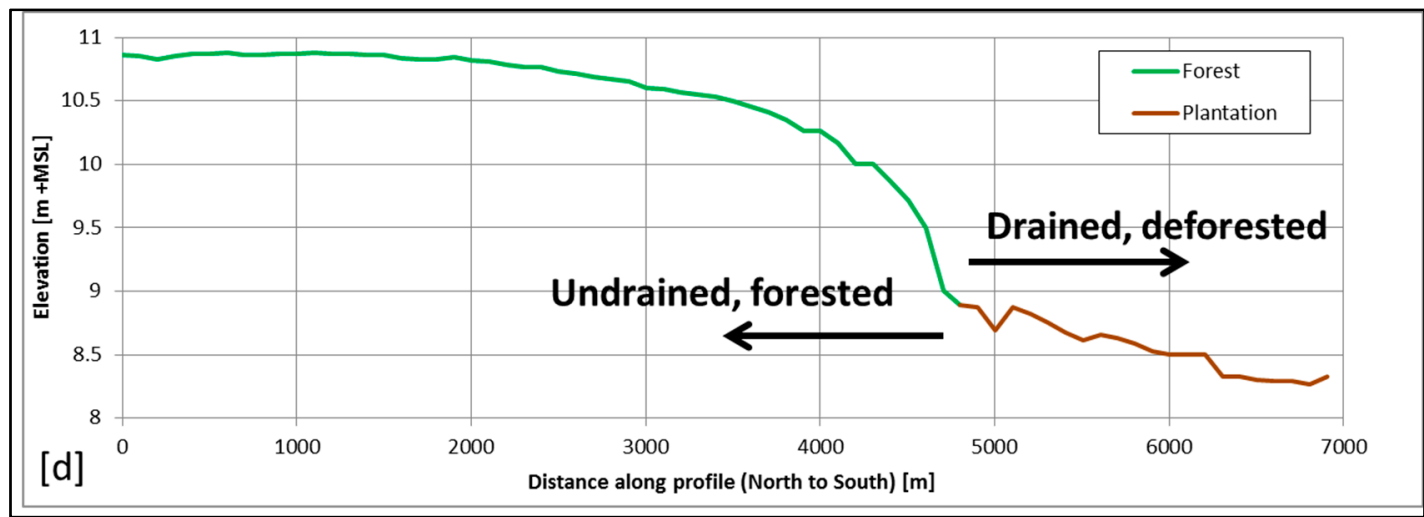

Figure 12. (a) 3D model of part of the Kampar Peninsula peat dome based on DTM presented in Figure 7. A zoomed-in version of the 3D model in Pelalawan district (indicated by the black square) is shown in (b,c) superimposed with forest [32] and plantation drainage canals with elevation profile location shown (d) by the black line. The plantation was created around 2002. The land surface subsidence in the plantation by over $1.5 \mathrm{~m}$ (in 15 years) is clearly visible from the 3D imagery as further illustrated in the elevation profile showing a drop of elevation of more than $1 \mathrm{~m}$ within the first $500 \mathrm{~m}$ from the plantation boundary canal.

It is evident from the DTM that land surface subsidence has substantially affected surface elevation in many areas of deep peat. Abrupt elevation changes of over $1 \mathrm{~m}$ occur over a few hundred metres across plantation boundary canals where one side is deforested and intensely drained and the other is still forested and less drained (Figure 12). Such local anthropogenic land surface subsidence features are the main cause of inaccuracy in the interpolated DTM, with the greatest differences between full coverage and interpolated DTMs occurring up to a few hundred meters away from canals as shown in Figure 5.

\section{Conclusions}

We have demonstrated that DTMs based on LiDAR data collected along parallel strips at $5 \mathrm{~km}$ intervals are accurate within $0.5 \mathrm{~m}$ and $1 \mathrm{~m}$ over $94.7 \%$ and $99.3 \%$, respectively, of the validation area of 616,000 ha (Table 1). This is sufficient for most purposes including flood risk assessments, water management design, land zoning and peat thickness mapping. We, therefore, recommend applying DTMs based on interpolation between partial coverage LiDAR in situations where accuracy requirements exceed the specifications of non-LiDAR data sources, but financial and time resources are insufficient for acquisition of full coverage LiDAR.

The peatland subsidence features identified (Figure 12) confirm that peat is lost to mostly oxidation (over 75\%; [14]) and some compaction after drainage, causing carbon emissions and increasing future flood risk. Accurate DTMs can help identify areas most affected by such impacts, and allow analyses of subsidence causes, rates, and mitigation options, especially if DTMs are updated in time as land surface subsidence progresses. In subsiding peatlands, any DTM can only be accurate for a limited amount of time, and it is better to think of DTM generation as monitoring rather than mapping.

As the East Sumatra DTM presented here covers most lowland $(63.6 \%)$ and peatland $(62.7 \%)$ in all of Sumatra, it provides a good basis for obtaining full lowland and peatland coverage for Sumatra with relatively limited effort.

The position of $36.3 \%$ ( $2.6 \mathrm{Mha}$ ) of the land surface in the East Sumatra DTM below $2.0 \mathrm{~m}+\mathrm{MSL}$, and the associated flood risk, are cause for concern, especially with rising sea levels. We recommend the use of accurate DTM data in assessments of current and future flood risk, and associated mitigation and adaptation options. 
The DTMs for the coastal lowlands of Central Kalimantan and East Sumatra, at $500 \mathrm{~m}$ resolution, are available for download (https://doi.org/10.17632/72r3bvdd3r.1) to be used in further analyses by Indonesian government, the scientific community and other stakeholders.

Author Contributions: Conceptualization: R.V., A.H., A.T.Y., and D.M.; data curation: R.V., A.T.Y., M.V., M.P., R.A., and N.F.; formal analysis: R.V., A.H., A.T.Y., M.V., M.P., D.E., D.M., H.A., J.O., and W.H.; funding acquisition: R.V. and A.H.; methodology: R.V., A.H., A.T.Y., M.V., M.P., and D.E.; software: M.V., M.P., and D.E.; writing-original draft: R.V., A.H., A.T.Y., and M.P.; writing—review and editing: M.V., D.E., R.A., H.A., and J.O.

Funding: Airborne LiDAR data acquisition was funded by the Australian Agency for International Development and Dutch government (2011), Norwegian Agency for Development Cooperation (2014), Asia Pulp and Paper (2015, 2016, 2017), Belantara Foundation (2017), United Kingdom Climate Change Unit (2017) and others.

Acknowledgments: Data acquisition was conducted by PT. Surtech Prima (www.surtech-group.com; 2011, 2015, 2016, 2017) and PT. ASI Pudjiastuti Geosurvey (www.geosurvey.co.id; 2014). We wish to thank three anonymous reviewers for their useful comments and suggestions that enabled us to improve the content of this paper.

Conflicts of Interest: The authors declare no conflict of interest. The funders had no role in the design of the study; in the collection, analyses, or interpretation of data; in the writing of the manuscript, and in the decision to publish the results.

\section{References}

1. McGranahan, G.; Balk, D.; Anderson, B. The rising tide: Assessing the risks of climate change and human settlements in low elevation coastal zones. Environ. Urban. 2007, 19, 17-37. [CrossRef]

2. Syvitski, J.P.M. Deltas at risk. Sustain. Sci. 2008, 3, 23-32. [CrossRef]

3. Nicholls, R.J. Impact of and responses to sea-level rise. In Understanding Sea-Level Rise and Variability; Church, J.A., Woodworth, P.L., Aarup, I., Wilson, W.S., Eds.; John Wiley \& Sons: Chichester, UK, 2010; pp. 17-44.

4. Hooijer, A.; Vernimmen, R.; Visser, M.; Mawdsley, N. Flooding Projections from Elevation and Subsidence Models for Oil Palm Plantations in the Rajang Delta Peatlands, Sarawak, Malaysia. Deltares Report 1207384. 2015. Available online: https:/www.deltares.nl/app/uploads/2015/06/Rajang-Delta-Peatland-Subsidence-FloodingDeltares-2015.pdf (accessed on 9 April 2019).

5. Hooijer, A.; Vernimmen, R.; Mawdsley, N.; Page, S.; Mulyadi, D.; Visser, M. Assessment of Impacts of Plantation Drainage on the Kampar Peninsula Peatland, Riau. Deltares Report 1207384 to Wetlands International, CLUA and Norad. 2015. Available online: https://www.deltares.nl/app/uploads/2015/12/Plantation-Impacts-KamparPeatland-DELTARES-2015.pdf (accessed on 9 April 2019).

6. Minderhoud, P.S.J.; Erkens, G.; Pham, V.H.; Bui, V.T.; Erban, L.; Kooi, H.; Stouthamer, E. Impacts of 25 years of groundwater extraction on subsidence in the Mekong delta, Vietnam. Environ. Res. Lett. 2017, 12, 064006. [CrossRef] [PubMed]

7. Syvitski, J.P.M.; Kettner, A.J.; Overeem, I.; Hutton, E.W.H.; Hannon, M.T.; Brakenridge, G.R.; Day, J.; Vörösmarty, C.; Saito, Y.; Giosan, L.; et al. Sinking deltas due to human activities. Nat. Geosci. 2009, 2, 681-686. [CrossRef]

8. Sampson, C.C.; Smith, A.M.; Bates, P.D.; Neal, J.C.; Trigg, M.A. Perspectives on open access high resolution digitial elevation models to produce global flood hazard layers. Front. Earth Sci. 2016, 3, 1-6. [CrossRef]

9. Hinkel, J.; Lincke, D.; Vafeidis, A.T.; Perrette, M.; Nicholls, R.J.; Tol, R.S.J.; Marzeion, B.; Fettweis, X.; Ionescu, C.; Levermann, A. Coastal flood damage and adaptation costs under 21st century sea-level rise. Proc. Natl. Acad. Sci. USA 2014, 111, 3292-3297. [CrossRef]

10. Neumann, B.; Vafeidis, A.T.; Zimmermann, J.; Nicholls, R.J. Future coastal population growth and exposure to sea-level rise and coastal flooding-A global assessment. PLoS ONE 2015, 10, e0118571. [CrossRef] [PubMed]

11. Yamazaki, D.; Ikeshima, D.; Tawatari, R.; Yamaguchi, T.; O’Loughlin, F.E.; Neal, J.C.; Sampson, C.C.; Kanae, S.; Bates, P.D. A high accuracy map of global terrain elevations. Geophys. Res. Lett. 2017, 44, 5844-5853. [CrossRef]

12. Ministry of Public Works, Directorate General of Water Resources Development. Sustainable Swamp Development: The Choice of Indonesia; Ministry of Public Works, Directorate General of Water Resources Development: Jakarta, Indonesia, 1996. 
13. Handoko, E.Y.; Fernandes, M.J.; Lazaro, C. Assessment of altimetric range and geophysical corrections and mean sea surface models - impacts on Sea level variability around the Indonesian seas. Remote Sens. 2017, 9, 102. [CrossRef]

14. Hooijer, A.; Page, S.; Jauhiainen, J.; Lee, W.A.; Lu, X.X.; Idris, A.; Anshari, G. Subsidence and carbon loss in drained tropical peatlands. Biogeosciences 2012, 9, 1053-1071. [CrossRef]

15. Abidin, H.Z.; Andreas, H.; Gamal, M.; Wirakusumah, A.D.; Darmawan, D.; Deguchi, T.; Maruyama, Y. Land subsidence characteristics of the Bandung Basin, Indonesia, as estimated from GPS and InSAR. J. Appl. Geodesy 2008, 2, 167-177. [CrossRef]

16. Abidin, H.Z.; Andreas, H.; Gumilar, I.; Fukuda, Y.; Pohan, Y.E.; Deguchi, T. Land subsidence of Jakarta (Indonesia) and its relation with urban development. Nat. Hazards 2011, 59, 1753-1771. [CrossRef]

17. Abidin, H.Z.; Andreas, H.; Gumilar, I.; Sidiq, T.P.; Fukuda, Y. Land subsidence in coastal city of Semarang (Indonesia): Characteristics, impacts and causes. Geomat. Nat. Hazards Risk 2013, 4, 226-240. [CrossRef]

18. Dahuri, R.; Rais, J.; Ginting, S.P.; Sitepu, M.J. Pengelolaan Sumber Daya Pesisir Dan Lautan Secara Terpadu, 1st ed.; Balai Pustaka: Jakarta, Indonesia, 2008.

19. Zhang, K.; Chen, S.C.; Whitman, D.; Shyu, M.L.; Yan, J.; Zhang, C. A progressive morphological filter for removing nonground measurements from airborne LiDAR data. IEEE Trans. Geosci. Remote Sens. 2003, 41, 872-882. [CrossRef]

20. Zhang, K.; Whitman, D. Comparison of three algorithms for filtering airborne LiDAR data. Photogramm. Eng. Remote Sens. 2005, 71, 313-324. [CrossRef]

21. Korzeniowska, K.; Pfeifer, N.; Mandlburger, G.; Lugmayr, A. Experimental evaluation of ALS point cloud ground extraction tools over different terrain slope and land-cover types. Int. J. Remote Sens. 2014, 35, 4673-4697. [CrossRef]

22. Lampela, M.; Jauhiainen, J.; Kämäri, I.; Koskinen, M.; Tanhuanpää, T.; Valkeapää, A.; Vasander, H. Ground surface microtopography and vegetation patterns in a tropical peat swamp forest. Catena 2016, 139, 127-136. [CrossRef]

23. Bezanson, J.; Edelman, A.; Karpinski, S.; Shah, V.B. Julia: A fresh approach to numerical computing. SIAM Rev. 2017, 59, 65-98. [CrossRef]

24. Isenburg, M. LASzip. Photogramm. Eng. Remote Sens. 2013, 79, 209-217. [CrossRef]

25. Deltares/als2dtm: Archived Version. Available online: https://zenodo.org/record/2657414\#.XNqIO9IRVPY (accessed on 9 April 2019).

26. Greenpeace. 2018. Available online: http://www.greenpeace.org/seasia/id/Global/seasia/Indonesia/Code/ Forest-Map/en/data.html (accessed on 14 December 2018).

27. Ritung, S.; Wahyunto; Nugroho, K.; Sukarman; Hikmatullah; Suparto; Tafakresnanto, C. Peta lahan gambut Indonesia. Skala 1:250.000; Balai Besar Penelitian dan Pengembangan Sumberdaya Lahan Pertanian: Bogor, Indonesia, 2011.

28. Nedeco/Euroconsult and BIEC. Nationwide Study of Coastal and Near-Coastal Swamp Land in Sumatra, Kalimantan and Irian Jaya: Final Report; Nedeco/Euroconsult: Arnhem, The Netherlands, 1984.

29. Konecny, K.; Ballhorn, U.; Navratil, P.; Jubanski, J.; Page, S.E.; Tansey, K.T.; Hooijer, A.; Vernimmen, R.; Siegert, F. Variable carbon losses from recurrent fires in drained tropical peatlands. Glob. Chang. Biol. 2016, 22, 1469-1480. [CrossRef]

30. Farr, T.G.; Rosen, P.A.; Caro, E.; Crippen, R.; Duren, R.; Hensley, S.; Kobrick, M.; Paller, M.; Rodriguez, E.; Roth, L.; et al. The Shuttle Radar Topography Mission. Rev. Geophys. 2007, 45. [CrossRef]

31. Wahyunto; Ritung, S.; Subagjo, H. Peta Luas Sebaran Lahan Gambut dan Kandungan Karbon di Pulau Sumatera/Map of Area of Peatland Distribution and Carbon Content in Sumatera, 1990-2002; Wetlands International-Indonesia Programme and Wildlife Habitat Canada (WHC): Bogor, Indonesia, 2003.

32. Margono, B.A.; Potapov, P.; Turubanova, S.; Stolle, F.; Hansen, M. Primary forest cover loss in Indonesia over 2000-2012. Nat. Clim. Chang. 2014, 4, 730-735. [CrossRef]

(C) 2019 by the authors. Licensee MDPI, Basel, Switzerland. This article is an open access article distributed under the terms and conditions of the Creative Commons Attribution (CC BY) license (http://creativecommons.org/licenses/by/4.0/). 